\title{
Incidence of Decreasing Population of House Crow (Corvus splendens) in Some Pockets of Malwa Region of Punjab, India
}

\author{
Manpreet Kaur* and K.S. Khera \\ Department of Zoology, Punjab Agricultural University, Ludhiana, Punjab, INDIA \\ "Corresponding author: M Kaur; E-mail: binner_manpreet@yahoo.com
}

Received: 07 July, 2020

Revised: 01 Dec., 2020

Accepted: 06 Dec., 2020

\begin{abstract}
Not long ago, House Crow was the most wide-spread member of the Corvidae family in Punjab. Then, scattered observations revealed a decline in the population of this species, even so, that very few could be seen in many parts of Punjab. Till now there is no study on the House Crow disappearance from Punjab or any other part of the world. The present study was conducted for two continuous years from June 2015-May 2017 to obtain data on the current status of the House Crow population and to determine the possible reasons for their decline in three selected locations, viz. Ludhiana, Sangrur, and Bathinda districts falling in the Malwa region of Punjab. The survey showed that the population of House Crow in some pockets of Punjab has shown a considerable decline. These declines are troubling because the disappearance of House Crow means loss of cost-free scavenger services provided by them. This study could be used to predict and investigate the population of House Crow in other parts of Punjab and provide the baseline information for conservation practices to be adopted for the species in the state.
\end{abstract}

\section{HIGHLIGHTS}

( Study was conducted on the dynamics of house crow population in some pockets of Malwa region of Punjab.

( It was observed that population of House Crow was significantly low at the Sangrur and Bathinda villages as compared to PAU, Ludhiana.

Keywords: Disappearance, Conservation, House Crow, Malwa region, Punjab

House Crow (Corvus splendens) is a bird nearly everybody loves to despise. 'Splendens' in Latin means splendid - a difficult descriptive word to utilize when we discussing crows. A crow intrudes itself on one's consideration, if not with its polished dark shading, then by its crowing and cawing sounds (Gadgil, 2001). Therefore, it is not unexpected that Corvus splendens is always viewed as a public nuisance in numerous nations. And it is due to several reasons. It causes much obvious harm. The list of its wrong doings is long and we can read it like a chargesheet of criminals. House crow imposes both economic and natural harm by predating on chicks and eggs, destroying crops, bringing on extreme harm to fruits in plantations (Kumar, 2004). Moreover, House crow is also known to cause a public health hazard (Archer, 2001), as the birds may carry disease organisms passively on their feet and bill. They could be picked up through their association with human excreta, refuses, and also through decomposing carcasses. As a result, they could result in the spreading of some bacteria like Salmonella and E. coli (Ryall, 2002). In many studies, they are also found to bear Cryptococcus neoformans, microscopic organisms that can bring about cryptococcosis in people (Gokulshankar et al., 2004).

But we, in India, are not managing an intruding pest. This is very much an Indian bird and we have all strolled the way together for a very long time. Nearly everybody in India knows about the House Crow. It pollutes, it victimizes,

How to cite this article: Kaur, M. and Khera, K.S. (2020). Incidence of decreasing population of house crow (Corvus splendens) in some pockets of Malwa region of Punjab, India. J. Anim. Res., 10(6): 993-1000. Source of Support: None; Conflict of Interest: None क् क्ष 
it assaults - we realize that and have figured out how to live with it (Sen, 2011). No city sunrise breaks without its raucous caw, cah setting up the residents for one more day of its shenanigans (Ramakrishna et al., 2014).

In any case, now, their annoying calls are not heard as often times as they used to be in some areas. Their absence, even though they are very little cherished birds, is increasingly becoming noticeable in some pockets of Punjab. The scattered observations revealed a decline in the population of this species (Bhanutej, 2014; Siddiqui, 2011), even so, that very few could be seen in many parts of southern Punjab. House Crow and their habitats were virtually underneath noticing both of ornithologists and academics, so few genuine investigations of the species were made and the outcome is a continuing scarcity of hard data on the population ecology of this species.

Although, Indian House Crow population is categorized under "least concern", according to IUCN list 2019. In any case, after the sensational decline of vulture species in the previous two decades and the moderate decrease of the house sparrow, demonstrate no species is sufficiently sheltered in this human-commanded world. For instance, in the 1990s, Gyps vultures of Asia were regarded as doing well as indicated by IUCN yet by 2001 the status of the bird had dived to that of basically jeopardized species. We don't know which different species face such terrible destiny shortly again (Rahmani, 2011). The present study aimed to know the current population status of House Crow in Ludhiana, Sangrur and Bathinda districts of Malwa region of Punjab.

\section{MATERIALS AND METHODS}

\section{Study area}

Population of House Crow was studied at the three study areas i.e. (i) Ludhiana district (ii) Sangrur district (iii) Bathinda district, thrice a month. Each area was further divided into five transects, totally therefore up to 15 transects. Each transect covered an area of 3-4 sq km (Table 1,2 and 3). Each area had a distinct diversity of cropland, food availability, water availability, etc. A complete record of different existing components including crops and trees in these habitats was maintained.

\section{Sampling time and Data collection}

For population count, the point count method was used in all selected transects to observe their daily diurnal activities. The three readings were averaged to get a mean figure for the House Crow Population. Mostly observations were taken in the morning between $8.00 \mathrm{AM}$ to $11.00 \mathrm{AM}$ from June 2015 to May 2017 at 10 sampling transects in Ludhiana and Sangrur districts. While in Bathinda district transects, observations were taken from December 2016 to May 2017. The number of House Crow was noticed either with the naked eye or with the help of binocular at a distance from the bird to avoid the disturbance to birds. The number of birds was correlated with the habitat of the area. Any change in the numbers/density was recorded.

All data were expressed as Mean \pm Standard Error and statistically analyzed by Non-parametric procedure (Kruskal-Wallis test) to determine a difference in the number of House Crow in different months as well as in different transects. And Non-parametric procedure (MannWhitney test) was applied to determine a difference in the number of House Crow in different districts.

\section{RESULTS AND DISCUSSION}

In the present study, it was observed that the population of House Crow was significantly low at the Sangrur and Bathinda villages as compared to PAU, Ludhiana. The average number of House Crow was ranged from $9.000 \pm 3.464$ to $47.666 \pm 4.055$ in 5 transects of Ludhiana district, $1.333 \pm 0.333$ to $16.333 \pm 0.881$ in 5 transects of Sangrur district, as shown in Table 4 and $1.333 \pm 0.333$ to $18.000 \pm 0.577$ in different transects of Bathinda district, shown in Table 5. A comparison of the average number of House Crow recorded in Ludhiana district and Sangrur district was given in Table 4 and Fig. 1 and 2. A comparison of the average number of House Crow recorded in Ludhiana district and Bathinda district was given in Table 5 and Fig. 3. And a comparison of the average number of House Crow recorded in Sangrur district and Bathinda district was given in Fig. 4.

From the statistical analysis (Kruskal-Wallis test), it was clear that the average number of House Crow was significantly different $(\mathrm{P}<0.05)$ in Ludhiana district and Sangrur district in different months in Transect I, II, III, V, VII, and VIII (Table 6) and also was significantly 
Table 1: Transects under Ludhiana district

\begin{tabular}{|c|c|c|}
\hline Transect No. & Name of the transect & Type of area \\
\hline I & $\begin{array}{l}\text { PAU Library road, Gate no. } 2 \text { Road and Nursery } \\
\text { area }\end{array}$ & Sports ground, Mela ground, trees, library building, roads \\
\hline II & $\begin{array}{l}\text { PAU Floriculture department area, gate no. } 7 \\
\text { road area }\end{array}$ & Flowers, agriculture fields, trees, landscape, water bodies, roads \\
\hline III & PAU New orchard area (Forestry area) & $\begin{array}{l}\text { Tree plantation mainly Popular, Eucalyptus and some other trees, } \\
\text { wastage dump }\end{array}$ \\
\hline IV & $\begin{array}{l}\text { PAU Museum, hostel no. 11, home science } \\
\text { college area }\end{array}$ & Lawns, trees and hostel dump, roads, building \\
\hline $\mathrm{V}$ & $\begin{array}{l}\text { PAU Orchard college area, Veterinary Hospital } \\
\text { Road area }\end{array}$ & Orchard, agriculture fields, buildings, trees, roads \\
\hline
\end{tabular}

Table 2: Transects under Sangrur district

\begin{tabular}{lll}
\hline Transect No. & Name of the transect & Type of area \\
\hline VI & Kalabula village & Agricultural fields, Roads, Trees \\
VII & Didargarh village & Agricultural fields, Roads, Trees \\
VIII & Ghanauri village & Agricultural fields, Roads, Trees \\
IX & Katron village & Agricultural fields, Roads, Trees \\
X & Bajwa village & Agricultural fields, Roads, Trees \\
\hline
\end{tabular}

Table 3: Transects under Bathinda district

\begin{tabular}{lll}
\hline Transect No. & Name of the transect & Type of area \\
\hline XI & Bhairupa village & Agricultural fields, Roads, Trees \\
XII & Dulewala village & Agricultural fields, Roads, Trees \\
XIII & Burj Gill village & Agricultural fields, Roads, Trees \\
XIV & DialpuraBhaika village & Agricultural fields, Roads, Trees \\
XV & Gumti Kalan village & Agricultural fields, Roads, Trees \\
\hline
\end{tabular}

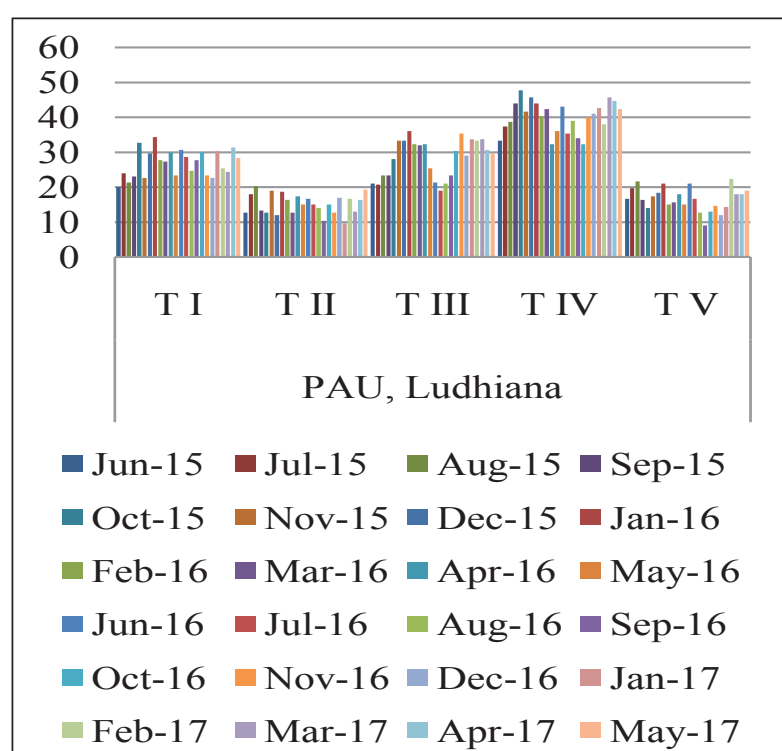

Fig. 1: Average number of House Crow sighted in different transects Ludhiana District

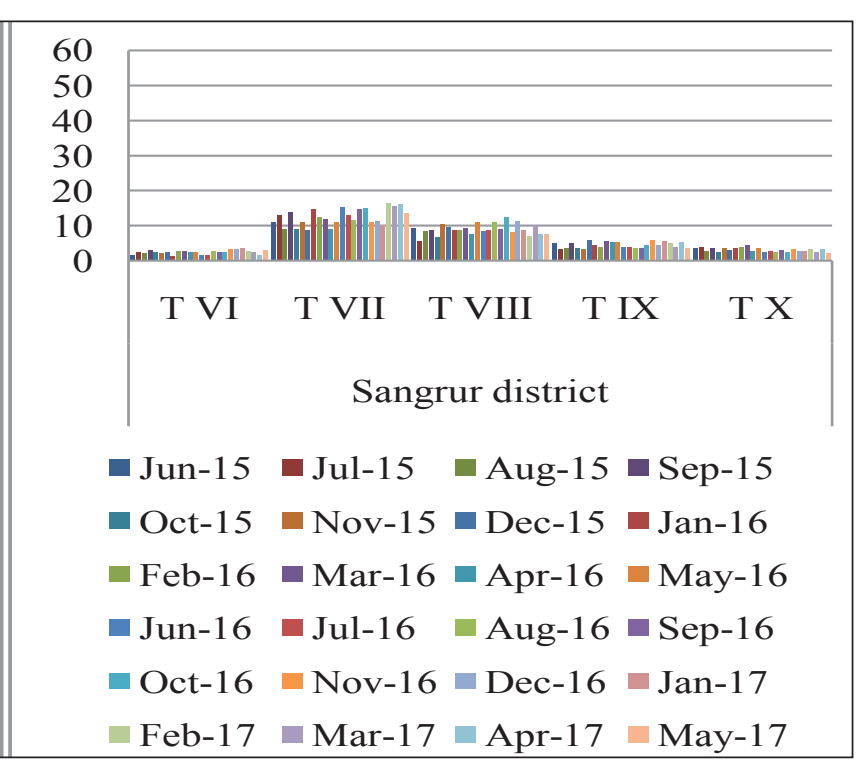

Fig. 2: Average number of House Crow sighted of in different transects of Sangrur district 


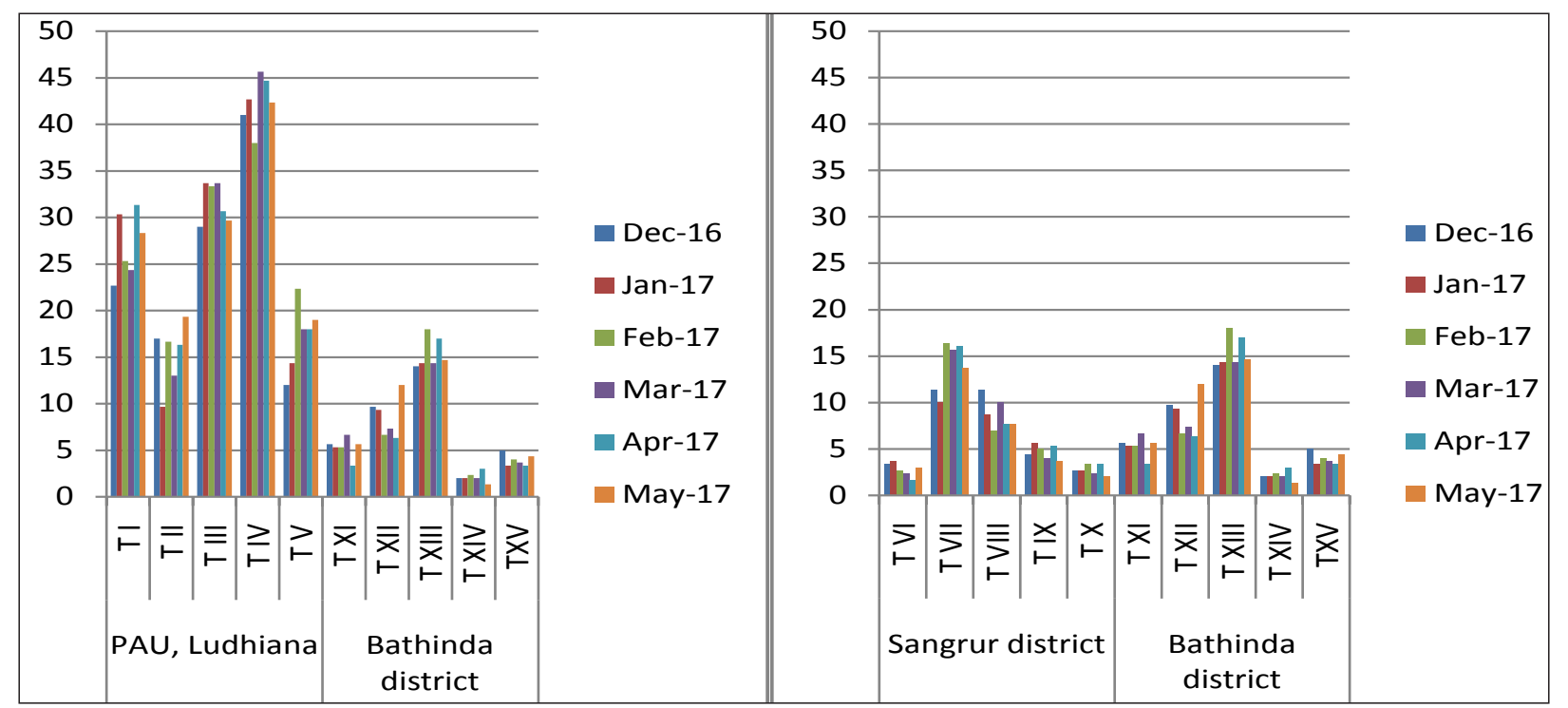

Fig. 1: Comparison of average number of House Crow recorded Fig. 4: Comparison of average number of House Crow recorded in Sangrur and Bathinda district in Ludhiana district and villages of Bathinda district

Table 4: Comparison of average number of House Crow sighted in different transects of Ludhiana district and Sangrur in different months

\begin{tabular}{|c|c|c|c|c|c|c|c|c|c|c|}
\hline \multirow{2}{*}{$\begin{array}{l}\text { Study area / } \\
\text { Transects } \rightarrow \\
\text { Months } \uparrow\end{array}$} & \multicolumn{5}{|c|}{ Ludhiana district } & \multicolumn{5}{|c|}{ Sangrur district } \\
\hline & T I & T II & T III & T IV & $\mathbf{T V}$ & T VI & T VII & T VIII & T IX & $\mathbf{T X}$ \\
\hline Jun-15 & $20.000 \pm 2.081$ & $2.666 \pm 1.763$ & $21.000 \pm 3.055$ & $3.333 \pm 1.855$ & $6.666 \pm 1.201$ & $1.666 \pm 0.333$ & $1.000 \pm 0.577$ & & $5.000 \pm 0.577$ & \\
\hline Jul-15 & $24.000 \pm 2.516$ & $18.000 \pm 1.732$ & $20.666 \pm 2.905$ & $37.333 \pm 5.634$ & $19.666 \pm 0.881$ & $2.333 \pm 0.333$ & $13.000 \pm 1.527$ & $5.666 \pm 2.185$ & $3.333 \pm 0.881$ & $4.000 \pm 0.577$ \\
\hline Aug-15 & $21.333 \pm 1.855$ & $20.333 \pm 0.881$ & $23.333 \pm 1.855$ & $38.666 \pm 1.763$ & $21.666 \pm 3.179$ & $2.000 \pm 0.577$ & $9.000 \pm 0.577$ & $8.333 \pm 0.881$ & $3.666 \pm 0.333$ & $2.666 \pm 0.333$ \\
\hline Sep-15 & $23.000 \pm 2.081$ & $13.333 \pm 1.855$ & $23.333 \pm 0.881$ & $44.000 \pm 2.645$ & $16.333 \pm 2.333$ & $3.000 \pm 0.577$ & $14.000 \pm 1.154$ & $8.666 \pm 1.452$ & $5.000 \pm 1.527$ & $3.666 \pm 0.881$ \\
\hline Oct-15 & $32.666 \pm 3.382$ & $12.666 \pm 1.452$ & $28.000 \pm 1.527$ & $47.666 \pm 4.055$ & $14.000 \pm 1.732$ & $2.333 \pm 0.577$ & $9.000 \pm 1.527$ & $6.666 \pm 0.881$ & $3.666 \pm 0.881$ & $2.333 \pm 0.666$ \\
\hline Nov-15 & $22.666 \pm 3.480$ & $19.000 \pm 1.732$ & $33.333 \pm 1.855$ & $41.666 \pm 4.409$ & $17.333 \pm 2.403$ & $2.000 \pm 0.577$ & $11.000 \pm 1.154$ & $10.333 \pm 0.881$ & $3.333 \pm 1.542$ & $3.666 \pm 0.881$ \\
\hline Dec-15 & $29.666 \pm 1.452$ & $12.000 \pm 1.732$ & $33.333 \pm 1.201$ & $45.666 \pm 4.484$ & $18.333 \pm 3.179$ & $2.333 \pm 0.333$ & $8.666 \pm 0.881$ & $9.666 \pm 0.881$ & $6.000 \pm 0.577$ & $3.000 \pm 0.577$ \\
\hline Jan-16 & & $18.666 \pm 1.452$ & $36.000 \pm 1.527$ & & & & & & & \\
\hline Feb-16 & & & & & & & & & & \\
\hline Mar-16 & $27.333 \pm 3.179$ & $12.666 \pm 1.763$ & & $42.333 \pm 3.282$ & $15.666 \pm 2.027$ & $2.666 \pm 0.333$ & $12.000 \pm 1.154$ & & $5.666 \pm 1.452$ & $4.333 \pm 0.666$ \\
\hline Apr-16 & $30.000 \pm 0.577$ & $17.333 \pm 1.452$ & $32.333 \pm 2.603$ & $32.333 \pm 2.027$ & $18.000 \pm 3.785$ & & $9.000 \pm 0.577$ & & & 2.66 \\
\hline May-16 & $23.333 \pm 2.403$ & $15.000 \pm 0.577$ & $25.333 \pm 2.603$ & $36.000 \pm 3.214$ & $15.000 \pm 1.732$ & $2.333 \pm 0.881$ & $11.000 \pm 0.577$ & & 763 & 3.66 \\
\hline Jun-16 & $30.666 \pm 2.027$ & $16.666 \pm 3.282$ & $21.333 \pm 2.905$ & $43.000 \pm 4.618$ & $21.000 \pm 1.154$ & $1.666 \pm 0.333$ & $15.333 \pm 0.666$ & & $4.000 \pm 0.577$ & $2.333 \pm 0.333$ \\
\hline Jul-16 & $28.666 \pm 2.403$ & $15.000 \pm 1.527$ & $19.000 \pm 1.154$ & $35.333 \pm 2.185$ & $16.666 \pm 2.905$ & $1.666 \pm 0.333$ & $13.000 \pm 1.154$ & $8.666 \pm 0.881$ & $4.000 \pm 1.154$ & $2.666 \pm 0.881$ \\
\hline$A$ & $24.666 \pm 1.201$ & $14.000 \pm 1.527$ & $21.000 \pm 3.214$ & $39.000 \pm 2.081$ & $12.666 \pm 0.881$ & $2.666 \pm 0.333$ & $11.666 \pm 1.201$ & $11.000 \pm 0.577$ & $3.666 \pm 0.666$ & $2.333 \pm 0.333$ \\
\hline Sor 1 & $27.666 \pm 1.763$ & $10.333 \pm 1.452$ & $23.333 \pm 2.027$ & $34.000 \pm 2.516$ & $09.000 \pm 3.464$ & $2.333 \pm 0.333$ & $14.666 \pm 1.333$ & & & $3.000 \pm 0.577$ \\
\hline Ont & $30.000 \pm 2.886$ & $15.000 \pm 0.577$ & $30.333 \pm 0.881$ & $32.333 \pm 1.452$ & $13.000 \pm 1.000$ & $2.333 \pm 0.881$ & $15.000 \pm 0.577$ & & $4.333 \pm 0.333$ & $2.333 \pm 0.666$ \\
\hline Nov-16 & $23.333 \pm 1.452$ & $12.666 \pm 1.201$ & $35.333 \pm 2.185$ & $40.000 \pm 1.154$ & $14.666 \pm 1.855$ & $3.333 \pm 0.333$ & $11.000 \pm 0.577$ & $8.000 \pm 0.577$ & $6.000 \pm 0.557$ & $3.333 \pm 0.666$ \\
\hline Dec-16 & $22.666 \pm 2.333$ & $17.000 \pm 1.154$ & $29.000 \pm 1.154$ & $41.000 \pm 1.527$ & $12.000 \pm 0.577$ & $3.333 \pm 0.666$ & $11.333 \pm 1.201$ & $11.333 \pm 0.881$ & $4.333 \pm 0.666$ & $2.666 \pm 0.881$ \\
\hline Jan-17 & $30.333 \pm 1.201$ & $9.666 \pm 0.881$ & $33.666 \pm 2.403$ & $42.666 \pm 2.027$ & $14.333 \pm 0.881$ & $3.666 \pm 0.333$ & $10.000 \pm 1.154$ & $8.666 \pm 0.333$ & $5.666 \pm 0.881$ & $2.666 \pm 0.333$ \\
\hline Feb-2017 & $25.333 \pm 2.403$ & $16.666 \pm 0.881$ & $33.333 \pm 1.855$ & $38.000 \pm 3.464$ & $22.333 \pm 1.452$ & $2.666 \pm 0.333$ & $16.333 \pm 0.881$ & $7.000 \pm 0.577$ & $5.000 \pm 1.154$ & $3.333 \pm 1.201$ \\
\hline Mar-2017 & $24.333 \pm 2.027$ & $13.000 \pm 1.527$ & $33.666 \pm 2.962$ & $45.666 \pm 1.855$ & $18.000 \pm 0.577$ & $2.333 \pm 0.881$ & $15.666 \pm 0.881$ & $10.000 \pm 0.577$ & $4.000 \pm 1.000$ & $2.333 \pm 0.333$ \\
\hline Apr-2017 & $31.333 \pm 0.881$ & $16.333 \pm 1.763$ & $30.666 \pm 0.881$ & $44.666 \pm 1.855$ & $18.000 \pm 1.527$ & $1.666 \pm 0.666$ & $16.000 \pm 1.000$ & $7.666 \pm 0.333$ & $5.333 \pm 0.881$ & $3.333 \pm 0.881$ \\
\hline May-2017 & $28.333 \pm 0.333$ & $19.333 \pm 0.666$ & $29.666 \pm 1.201$ & $42.333 \pm 2.027$ & $19.000 \pm 0.577$ & $3.000 \pm 0.577$ & $13.666 \pm 1.855$ & $7.666 \pm 0.881$ & $3.666 \pm 0.333$ & $2.000 \pm 1.000$ \\
\hline
\end{tabular}


Table 5: Average number of House Crow sighted in different transects of Bathinda district in different months

\begin{tabular}{llllll}
\hline $\begin{array}{l}\text { Study area / } \\
\text { Transects } \\
\text { Months } \downarrow\end{array}$ & T XI & T XII & T XIII & T XIV & T XV \\
\cline { 2 - 6 } Dec-16 & $5.666 \pm 0.333$ & $9.666 \pm 0.881$ & $14.000 \pm 1.527$ & $2.000 \pm 0.577$ & $5.000 \pm 0.577$ \\
Jan-17 & $5.333 \pm 0.881$ & $9.333 \pm 1.452$ & $14.333 \pm 1.855$ & $2.000 \pm 1.000$ & $3.333 \pm 0.333$ \\
Feb-2017 & $5.333 \pm 1.452$ & $6.666 \pm 0.666$ & $18.000 \pm 0.577$ & $2.333 \pm 0.333$ & $4.000 \pm 1.154$ \\
Mar-2017 & $6.666 \pm 1.201$ & $7.333 \pm 1.201$ & $14.333 \pm 1.763$ & $2.000 \pm 0.577$ & $3.666 \pm 0.666$ \\
Apr-2017 & $3.333 \pm 0.666$ & $6.333 \pm 0.333$ & $17.000 \pm 1.527$ & $3.000 \pm 0.577$ & $3.333 \pm 0.881$ \\
May-2017 & $5.666 \pm 0.333$ & $12.000 \pm 0.577$ & $14.666 \pm 1.666$ & $1.333 \pm 0.333$ & $4.333 \pm 0.881$ \\
\hline
\end{tabular}

Table 6: Non-parametric procedure (Kruskal-Wallis test) showing difference in number of House Crow in different months in transects (I-X)

\begin{tabular}{lllllllllll}
\hline Transects & TI & TII & TIII & TIV & TV & TVI & TVII & TVIII & TIX & TX \\
\hline Chi-Square & 41.830 & 45.170 & 55.959 & 35.13 & 39.516 & 27.515 & 48.006 & 37.764 & 18.869 & 21.539 \\
Df & 23 & 23 & 23 & 23 & 23 & 23 & 23 & 23 & 23 & 23 \\
Asymp. Sig. & 0.010 & 0.004 & 0.000 & 0.050 & 0.017 & 0.235 & 0.002 & 0.027 & 0.709 & 0.548 \\
\hline
\end{tabular}

Kruskal Wallis Test; Grouping Variable: Month; 'T' represents transect (I-X)

Table 7: Non-parametric procedure (Kruskal-Wallis test) showing difference in number of House Crow in different transects of Ludhiana and Sangrur districts

\begin{tabular}{lll}
\hline Transects & Ludhiana district & Sangrur district \\
\hline Chi-Square & 273.625 & 285.628 \\
Df & 4 & 4 \\
Asymp. Sig. & 0.000 & 0.000 \\
\hline
\end{tabular}

Kruskal Wallis Test; Grouping Variable: Transect

Table 8: Non-parametric procedure (Mann-Whitney test) showing difference in number of House Crow in different transects Ludhiana and Sangrur district

\begin{tabular}{ll}
\hline District & Ludhiana/Sangrur \\
\hline Mann-Whitney U & $3.154 \mathrm{E} 3$ \\
Wilcoxon W & $6.813 \mathrm{E} 4$ \\
Z & -22.110 \\
\hline Asymp. Sig. (2-tailed) & $\mathbf{0 . 0 0 0}$ \\
\hline
\end{tabular}

Mann-Whitney Test; Grouping Variable: District.

different $(\mathrm{P}<0.05)$ in different Transects in Ludhiana and Sangrur districts. Also from Table 14, it was concluded that the number of House Crow was significantly different $(\mathrm{P}<0.05)$ in both districts (Table 7). In both districts, a highly significant $(\mathrm{P}<0.05)$ statistical difference was recorded (Table 8).
Furthermore, the average number of House Crow in Bathinda district in different months in Transect XII was significantly different $(\mathrm{P}<0.05)$ (Table 9). Moreover, the average number of House Crow was also significantly different $(\mathrm{P}<0.05)$ in different Transects in Bathinda districts (Table 9). In Ludhiana and Bathinda districts, 
Table 9: Non-parametric procedure (Kruskal-Wallis test) showing difference in number of House Crow in different months in transects as well as in different transects of Bathinda district (XI-XV)

\begin{tabular}{llllll}
\hline Transect & TXI & TXII & TXIII & TXIV & TXV \\
\hline Chi-Square & 6.782 & 11.327 & 6.060 & 4.544 & 3.803 \\
Df & 5 & 5 & 5 & 5 & 5 \\
\hline Asymp. Sig. & $\mathbf{0 . 2 3 7}$ & $\mathbf{0 . 0 4 5}$ & $\mathbf{0 . 3 0 0}$ & $\mathbf{0 . 4 7 4}$ & $\mathbf{0 . 5 7 8}$ \\
\hline
\end{tabular}

Kruskal Wallis Test; Grouping Variable: Month/Transect.

Table 10: Non-parametric procedure (Mann-Whitney test) showing difference in number of House Crow in Transects of Ludhiana and Bathinda districts

\begin{tabular}{ll}
\hline Transects & Ludhiana and Bathinda districts \\
\hline Mann-Whitney U & 299.000 \\
Wilcoxon W & $4.394 \mathrm{E} 3$ \\
Z & -10.739 \\
\hline Asymp. Sig. (2-tailed) & $\mathbf{0 . 0 0 0}$ \\
\hline
\end{tabular}

Mann-Whitney Test; Grouping Variable: District.

Table 11: Non-parametric procedure (Mann-Whitney test) showing difference in number of House Crow in Sangrur and Bathinda district

\begin{tabular}{ll}
\hline District & Sangrur and Bathinda \\
\hline Mann-Whitney U & $3.821 \mathrm{E} 3$ \\
Wilcoxon W & $7.916 \mathrm{E} 3$ \\
Z & -0.658 \\
\hline Asymp. Sig. (2-tailed) & $\mathbf{0 . 5 1 1}$ \\
\hline
\end{tabular}

Mann-Whitney Test; Grouping Variable: District.

a highly significant $(\mathrm{P}<0.05)$ statistical difference was recorded (Table 10). But, statistical difference recorded in the average number of House Crow was highly insignificant; $\mathrm{P}>0.05$ (Table 11) in Sangrur and Bathinda districts.

According to these results, it was observed that the population of House Crow was significantly different at the Ludhiana district and the Sangrur district as well as in the Ludhiana district and the Bathinda district. But no significant difference in population was observed in transects of Sangrur district and Bathinda district. Also, the number of birds was significantly high in Ludhiana district as compared to the Sangrur district and Bathinda District. This could be due to the habitat of Ludhiana district i.e. a large number of trees available, high tree diversity, and surplus food available. And also due to ideal agricultural practices which are followed here. Barbieri and De Andreis 1991; Johnston and Janiga, 1985, reported that greater food-resource accessibility and higher availability of roosting-breeding sites are the main factors to explain the relationship between location and flocking density. Sachhi et al. (2006) reported that, the populations of birds were mainly regulated by its ecological factors, hence, the population density remained similar due to the constant availability of roosting sites, nesting sites, food, and water points. According to Marzluff and Neatherlin (2006) and Richner (1992), availability of abundant food caused increased fecundity and survival in House Crow. Even if the survival or reproductive success of individual crows did not improve because of increased crowdedness in preferred habitats, density, which is an important indicator of habitat quality (Van, 1983), was elevated in food-rich habitat types. Direct evidence for this was found by Lim et al. (2003), count-based study. Like House Crow, 
Black Kite (Milvus migrans) is also an omnivorous bird. Kumar (2013), observed a high number of Black Kite in different transects of PAU, Ludhiana, this indicates the ideal environmental conditions of PAU, Ludhiana is suitable for these omnivorous birds.

But the Population of House Crow was significantly low in Sangrur district and Bathinda district of Punjab. To address why these declines are occurring, this study investigated possible reasons for the low population of House Crow in Sangrur and Bathinda districts. Preliminary examination suggests that the food shortage, fewer trees, less tree diversity, increased sanitization, stoppage of animal carcasses disposal in focal points, environmental pollution (pesticides and heavy metals) and even some internal factors, for instance, low reproductive rate, etc. could be the reasons for their decrease number in these pockets of Malwa region of Punjab. This initial finding was also supported by Fisher and Owens (2004). According to them, extrinsic threats like loss of habitat, change in climate and predationare the major probable reasons for decrease in population. According to Lack (1954), food shortage was the main natural factor limiting the numbers of many birds, in particular, the reproductive rate. Food shortage can also affect birds directly, by causing the breeding failure (Newton, 1998). However, Barbieri and De Andreis (1991) and Johnston and Janiga (1985), believed that greater food-resource accessibility and higher availability of roosting-breeding sites are the main factors to explain the relationship between location and flocking density. According to Siriwardena et al. (2008), pesticides would indirectly affect the invertebrate organisms as they are used to kill them. This would result in a decrease in invertebrate food on which these species depend. Directly, both pesticides and heavy metals could affect the survival of this species by decreasing their reproductive function. Therefore, these findings suggest that a long term monitoring over various habitats will provide perfect population trends.

\section{CONCLUSION}

It can be concluded that the population of House Crow has shown a decline in the recent past in some pockets of Punjab. Further sustained studies are required to list the most probable causes of the decline and come out with a suitable conservation strategy to arrest the decline.

\section{REFERENCES}

ANI, 2009. House sparrows facing extinction in Punjab. IST Ludhiana/Agency, 20: 23.

Archer, A.L. 2001. Control of the Indian house crow (Corvus splendens), in Eastern Africa. Ostrich. Suppl., 15: 147-152.

Barbieri, F. and Andreis, C. 1991. Investigation into the presence of pigeons (Columba livia forma domestica) in downtown Pavia and Oltrepò. Suppl. Ric. Biol. Game., 17: 195-198.

Bhanutej, N. 2014. The Indian house crow slowly disappearing from Bengaluru. http://etapps.indiatimes.com/

Crowe, O. 2012. Developing Birds as Indicators in Ireland. Final report to the Heritage Council Prepared by Olivia Crowe, BirdWatch Ireland, pp. 1-33.

Fisher, D.O. and Owens, I.P.F. 2004. The comparative method inconservation biology. Trends. Ecol. Evol., 19: 391-398.

Gadgil, M. 2001. Project Lifescape: Crows. Resonance., pp. 7482.

Gokulshankar, S., Ranganathan, S., Ranjith, M.S. and Ranjithsingh, A.J.A. 2004. Prevalence, serotypes and mating patterns of Cryptococcus neoformans in the pellets of different avifauna in Madras, India. Mycoses, 47: 310-314.

Hole, D.G., Whittingham, M.J., Bradbury, R.B., Anderson, G.Q.A., Patricia, L.M., Lee, P.L.M., Wilson, J.D. and Krebs, J.R. 2002. Agriculture: widespread local House sparrow extinctions. Nature, 418: 931-932.

Johnston, R.F. and Janiga, M. 1985. Pigeons. Oxford University Press, New York.

Kumar, A.C. 2004. Geophagy by three species of crows near carcass dumping ground at Jodhpur, Rajasthan. Newsletter. Ornithologists., 1(5): 71.

Lack, D. 1954. The natural regulation of animal numbers. Clarendon Press, Oxford, UK, pp. 214.

Lim, H.C., Sodhi, N.S., Brook, B.W. and Soh, M.C.K. 2003. Undesirable aliens: factors determining the distribution of three invasive bird species in Singapore. J. Trop. Ecol., 19: 685-695.

Marzluff, J.M. and Neatherlin, E. 2006. Corvid response to human settlements and campgrounds: causes, consequences, and challenges for conservation. Biol. Conserv., 130: $301-$ 314.

Mukherjee, A. 2003. More mobiles, and sparrows take flight. $\mathrm{http}: / /$ www.thehindubusinessline.com/2003/

Mustafa, I., Arif, N., Hussain, S.M., Malik, I.U., Javid, A., Ullah, M.I., Asif, S., Khan, M.R., Waqas, A., Equani, S.A.M., Irum, S. and Ahmed H. 2015. Study of population dynamics of House Sparrow (Passer domesticus) and House Crow (Corvus splendens) in Punjab (District Sarodha), Pakistan. Pakistan J. Zool., 47(4): 1147-1155. 
Newton, I. 1998. Population limitation in Birds. Academic Press Limited, USA, pp. 147.

Rahmani, A.R. 2011. Bird decline, insect decline and neonicotinoids: exploring the connections. http:// www.farmlandbirds.net/content/india\%E2\%80\%99sdisappearing-bird-species

Ramakrishna, S., Alexander, R., Deepak, P. and Jayashankar, M. 2014. Review on eco-biology of the House Crow, Corvus splendens, (Corvidae: Passeriformes). Internat. J. Sci. Res., 3(6): 488-490.

Richner, H. 1992. The effect of extra food on fi tness in breeding carrion crows. Ecol., 73: 330-335.

Ryall, C. 2002. Further record of range extinction in the House crow Corvus splendens. Bull. Brit. Ornithol. Club., 122(3): 231-240.
Sen, S. 2011. In praise of crows. http://birdsofindia-ssen. blogspot.in/2011/08/inpraise-of-crows.html. Accessed on 29 December 2013.

Siddiqui, F.R. 2011. Crows do a vanishing act. http://timesofindia. indiatimes.com/

Siriwardena, G.M., Baillie, S.R. and Wilson, J.D. 2008. Temporal variation in the annual survival rates of six granivorous birds with contrasting population trends. Ibis., 141: 621-636.

Summers-Smith, J.D. 2003. The decline of the House sparrow: a review. Brit. Birds., 96:439-446.

Van, H.B. 1983. Density as a misleading indicator of habitat quality. J. Wildlife. Manage., 47: 893-901. 